\title{
Integration of some biopesticides against potato tuber moth, Phthorimaea operculella (Zell.), during storage with reference to histopathological changes detected by a transmission electron microscope in the endocrine system
}

Aziza Mohamed Fouad Sharaby ${ }^{1}$, Mohamed Ahmed Gesraha ${ }^{*^{*}}$ (D) and Sahar Ahmed Baker Fallatah²

\begin{abstract}
Background: The potato tuber moth (PTM), Phthorimaea operculella (Zeller) (Lepidoptera: Gelechiidae), is an important pest. It attacks several cultivated solanaceous plants including potato (Solanum tubersum), tobacco (Nicotiana tabacum), eggplant (Solanum melonguene), tomato (Lycopersicom esculentum), and bell pepper (Capasicum annuum). It has also been reported to be found on several wild plant hosts of the following genera: Solanum, Datura, Nicotiana, Fabina, Hyoscyamus, Physalodes, Lycium, and Nicandra. All over the world, it is the most important insect pest in potato field and storage under subtropical warms and dry summer conditions. The larvae attack both foliage and tubers in the field and infested tubers brought into heaps.

Aim of work: This research focuses on (a) the compatibility of Bacillus thuringiensis (Dipel-2X DF) and granulosis virus (GV virus) with plant basil extract (Ocimum basilicum), an aromatic plant, as a component of integrated pest management system against the potato tuber moth during storage and (b) histopathological changes detected in the endocrine system by a transmission electron microscope.

Methods: 1. Insect culture rearing

A stock laboratory colony of PTM was initiated on potato tubers. The culture was maintained following the method of Sharaby and Fallatah (Bull NRC Egypt 43: 79-85, 2019). The culture and all experiments were maintained under room conditions of $27 \pm 2^{\circ} \mathrm{C}$ and $70 \pm 5 \% \mathrm{RH}$ with a light regime (10:14 L:D). New clean potato tubers were added every 10 days for egg deposition and to keep a continuous culture.

2. Basil plant extract

All parts of the basil plant (Ocimum basilicum) which was obtained from fields in June after 3 months of plantation were dried in a shad place then minced into fine powder in an electric mill. The weight of the plant powder $(500 \mathrm{~g})$ was filled into the Soxhlet apparatus and extracted with ethanol (85\%) that was used as a solvent.

3. Biological aspects of plant basil extract and the microbial insecticides (Dipel-2X DF (32,000 international units of potency/mg (equivalent to 32 billion international units of potency/KG Registration NO. 26508) and (Continued on next page)
\end{abstract}

\footnotetext{
*Correspondence: mgesraha@gmail.com

'Pests \& Plant Protection Department, Agricultural \& Biological Researches

Division, National Research Centre, Cairo, Egypt

Full list of author information is available at the end of the article
} 
(Continued from previous page)

granulosis virus (GV))

Basil extract was mixed with the microbial insecticides in order to study the combined effects on different biological aspects. Five millilitres of each of the tested substances (basil extract + B.t + GV) was mixed with 95-g commercial carrier material (talcum powder) and left to dry under room temperature; then, $1 \mathrm{~kg}$ of potato was treated by $25 \mathrm{~g}$ of the treated talcum powder $\mathrm{w} / \mathrm{w}$ (to be used as dust). The three bioagents were tested separately and in different combinations. Two control groups were used (treated talcum powder and the other talcum powder without treatment). Different biological parameters and development of PTM were estimated.

Electron microscopic studies: The remaining alive treated larvae were collected from inside the treated tubers after 13 days of hatching. Larvae were taken for ultrastructure investigations using the transmission electron microscope (TEM). To investigate the ultrastructure changes on the endocrine glands of the treated larvae, the brain neurosecretory cells, corpus cardiacum, corpus allatum, and prothoracic gland, were examined. Untreated larvae of the same age were used as control.

Results: In the data recorded, it is clear that there are insignificant differences at $P<0.01$ of the mean number of deposited eggs that were laid on potato tubers treated by talcum powder mixed with the three additives (basil extract + B.t + GV) (3.0 eggs/o) and on tuber treated by powder containing basil extract only (4.6 eggs/ + ) and nearly equal difference in the B.t + extract or GV + extract (cleared 4.0 and 5.0 eggs/ 9 , respectively); no differences in treatments by B.t or GV when used separately were found compared with the two control treatments of talcum powder only or the untreated tubers (38.2 eggs/ + ).

The most effective combination was the mixture of the three additives: the mean number of emerged adults was 0.4 , while it ranged from 1.2 to 14.4 for the other treatments compared with the two controls 35.4 and 37.2 individuals. The percentage of emerged $F_{1}$ was greatly decreased by the different treatments, and the lowest percentage (13.3\%) was recorded for extract + B.t + GV; for other treatments, the percentage ranged from 25.00 to $54.96 \%$ compared with 92.20 and $98.40 \%$ in the two control treatments. Histopathological changes on the endocrine glands of the larvae that were detected by the electron microscope have been recorded.

Conclusion: This research revealed that an additive effect was produced using a combination of three bioagents (basil plant extract + B.t + GV) against the potato tuber moth Phthorimaea operculella. The combination of the three elements in one formulation may reduce the initial amount of potato destruction, decrease insect resistance build-up, and reduce the need for chemical insecticides and their associated risks. The obtained results suggested an interesting opportunity to develop bio-insecticides based on plant extracts for the control of this serious lepidopteran pest and other pests during storage, so usage of the mentioned combined mixture for controlling and protecting the tubers from increasing their toxicity could be recommended.

Keywords: Phthorimaea operculella, Bacillus thuringiensis, GV virus, Basil extract, Endocrine system, Transmission electron microscope

\section{Background}

The potato tuber moth (PTM), Phthorimaea operculella (Zeller) (Lepidoptera: Gelechiidae), is an important pest. It attacks several cultivated solanaceous plants including potato (Solanum tubersum), tobacco (Nicotiana tabacum), eggplant (Solanum melonguene), tomato (Lycopersicom esculentum), and bell pepper (Capasicum annuum). It has also been reported to be found on several wild plant hosts of the following genera: Solanum, Datura, Nicotiana, Fabina, Hyoscyamus, Physalodes, Lycium, and Nicandra (Schaub and Kroschel 2018). The potato is considered the main host to this insect in different parts of the world (Sharaby et al. 2002). It causes serious damage to potato crops in both fields and storage (Rondon 2010). Larvae mine in tubers making them unsuitable for sale and consumption. Damage increases rapidly when several generations develop during the storage period. Biopesticides are certain types of pesticides derived from animals, plants, bacteria, and certain minerals (Srinivasan 2012). Indiscriminate pesticide use is detrimental to the environment and human health and increases insect resistance to pesticides. Alternative pest management strategies are warranted to reduce the misuse of pesticides in vegetables. Despite several constraints, biopesticides are being used in vegetable production systems. Microbial pesticides consist of a microorganism as the active ingredient: all the entomopathogenic bacteria, viruses, and fungi. Botanical pesticides have environmentally friendly characteristics such as 
volatile nature and low environmental risk compared to current synthetic pesticides. Due to minimal residual activity, predation, parasitism, and the number of pollinator insects would affect smaller and compatible IPM programs (Xu 2011). Biopesticides have an important role in crop protection, although most commonly in combination with other tools including biochemical pesticides as part of bio-intensive integrated pest management (Mazid et al. 2011). Recently, numerous studies indicated that many wild medicinal and ornamental plants have pesticidal properties which show antifeedant, repellent, growth regulator effects, and toxic activities on a wide range of insect pests (Stevenson 2014 and Onu et al. 2015). Bioactive compounds of plant origin are considered as an ecologically safe alternative, and the plant extracts with complex mixtures of compounds have been widely investigated for their insecticidal repellent, ovicidal, antifeedant, and antioviposition properties. There is an increasing interest in the role of the plant products in insect-plant interaction, particularly in host acceptance and rejection (Akhtar and Isman 2004). Endocrine-disrupting compounds (EDC) are known as third-generation insecticides. They act as insect growth regulators (IGR) and are considered as potential endocrine disruptors. They interfere with the hormonal system of insects causing adverse effects on the physiological function of the insect or on their progeny. Insect endocrinology is currently an active area of research because it offers the potential for disrupting the life cycle of the insect pest without harms to the environment.

This research focuses on the compatibility of Bacillus thuringiensis (Dipel-2X DF) and granulosis virus (GV virus) with plant basil extract (Ocimum basilicum), an aromatic plant, as a component of integrated pest management system against the potato tuber moth during storage. Histopathological changes detected in the endocrine system were undertaken by the transmission electron microscope.

\section{Methods}

\section{Insect culture rearing}

A stock laboratory colony of PTM was initiated on potato tubers, Solanum tuberosom (Spunta variety). The culture was maintained in rearing wooden cages, the front and back wall cage was with fine wire gauze and the tope with a movable door, provided with a fastened sleeve cloth for insect handling. The cage floor was covered by a layer of clean sand as a site for PTM larval pupation, following the method of Sharaby and Fallatah (2019). The culture and all experiments were maintained under room conditions of $27 \pm 2{ }^{\circ} \mathrm{C}$ and $70 \pm 5 \% \mathrm{RH}$ at a light regime of the day 10:14 h L:D. New clean potato tubers were added every 10 days for egg deposition and to keep a continuous culture.

\section{Basil plant extract}

All parts of the basil plant (Ocimum basilicum) (Labiacae) which was obtained from field at June after 3 months of plantation were dried in a shad place then minced into fine powder in an electric mill. Known weight $(500 \mathrm{~g})$ of the plant powder was filled into the Soxhlet apparatus. The required solvent (ethanolic alcohol 85\%) was filled up five times more than the total amount of the sample material into the flask of the apparatus. The apparatus was then connected with the water supply to the condenser. The temperature of the heating mantle was maintained at $65-70{ }^{\circ} \mathrm{C}$. The process was carried out for $6-8 \mathrm{~h}$. The extract was filtered to remove particular matter. The extract was dried under reduced pressure using Rota vapour. The evaporated material was weighed and stored in the refrigerator for further use. The desired stock solution of the extract was made by adding more solvent until the plant material was dissolved completely.

\section{Microbial insecticides}

a) Granulosis virus (GV) was obtained from the Plant Protection Institute, Ministry of Agriculture, Egypt, and was originally isolated from $P$. operculella.

b) Dipel-2X DF, biological insecticide, Bacillus thuringiensis, B.t subsp. Kurstaki strain HD-1, dry flowable (wettable granules), was obtained from Valent Bioscience Canada, Ltd., Toronto, Ontario (32,000 international units of potency/mg (equivalent to 32 billion international units of potency/KG Registration NO. 26508)).

\section{Biological aspects of the plant basil extract and the microbial insecticides}

Basil extract was mixed with the microbial insecticides in order to study the combined effects on different biological aspects and to calculate the damage index. Five millilitres of each of the tested substances (basil extract + B.t + GV) was mixed with 95-g commercial carrier material (talcum powder) and then left to dry under room temperature (to be used as dust). One kilogramme of potato tubers, submerged and allowed to dry, was treated by $25 \mathrm{~g}$ of the treated talcum powder $(w / w)$ shacked for a good mixing, until tubers were uniformly covered and the powders stick well to the tuber surfaces. The treated tubers were then distributed into five glass jars (1-L capacity), and six newly emerged moths were chosen from the stock culture $\left(3+{ }^{2}+3\right)$, introduced inside each jar, and covered with a piece of black organza 
cloth. Each experiment was arranged completely randomized at room temperature of $27 \pm 2{ }^{\circ} \mathrm{C}$. Eggs that were laid on the treated tubers were collected daily for 10 days, and the infested tubers were collected every day up to the end of egg deposition at each treatment. The total number of the deposited eggs/treatment was counted. The infested tubers at each treatment were left to complete larval development. Pupation and emergence of new moths $\left(F_{1}\right)$ after different treatments was calculated. For the control treatments, there were two controls: (1) tubers were left without treatments at the same conditions and another control (2) tubers treated with talcum powder only. Biological aspects evaluated were as follows: number of deposited eggs/treatment, percentage of emerged moths $\left(F_{1}\right)$, and duration of life cycle (egg to adult).

\section{Mean index of tuber damage}

The assessment of the mean index of tuber damages was determined according to Fenemore (1980); substance was tested separately and in different combinations.

\section{Electron microscopic studies}

The remaining surviving treated larvae were obtained from inside the treated tubers after 13 days post hatching on the tubers. Larvae were taken for ultrastructure investigations using the transmission electron microscope (TEM) fixed immediately in $4 \%$ glutaraldehyde. Untreated larvae of the same age were used as control. The head with the thorax was cut from the treated and normal larvae. Specimens were kept in the fixative at $4{ }^{\circ} \mathrm{C}$ till processed. To investigate the ultrastructure changes, the brain neurosecretory cells, corpus cardiacum, corpous allatum, and the prothoracic gland, were examined using the method described by Salama and Sharaby (1985) after being investigated by Zies EM/10 electron microscopy at $60 \mathrm{kV}$.

\section{Statistical analysis}

The mortality rate was corrected, using Abbott's formula (Abbott 1925). All data were statistically subjected to analysis of variance (ANOVA) through statistical package, Mstat-C Computer program, and significantly different means were separated using least significant difference (LSD).

\section{Results}

Data recorded in Table 1 cleared insignificant differences at $P<0.01$ for the mean number of deposited eggs that were laid on potato tubers treated by talcum powder mixed with the three additives (basil extract + B.t + GV) (3 eggs/female) and on tuber treated by powder containing basil extract only (4.6 eggs/female) and nearly equal difference in the case of B.t + extract or GV + extract
(4.6 and 5.0 eggs/female, respectively); no differences were found in treatments either by B.t or GV when they were used separately compared with the two control treatments of talcum powder only or the untreated tubers (38 eggs/female).

Duration in insect life cycle after hatching on the treated tubers into larvae was completed during their growth and development inside the tubers to pupae then the adult moth's offspring emerged. The longest period was 42.6 days in the case of treatment with the three additive substances; in other treatments, the duration ranged between 40.6 and 41.4 days compared with 32.0 days in the control.

Percentage of emerged $F_{1}$ was significantly decreased by the different treatments: the lowest percentage was recorded for extract + B.t + GV which was $13.3 \%$; for other treatments, the percentage ranged from 25 to 54.96\% compared with 92.2 and $98.4 \%$ in the two control treatments. The most effective combination was the mixture of the three additives which obtained the mean number of emerged adults of $0.4 \%$, while the mean number ranged from 1.2 to $14.4 \%$ for the other treatments compared with the controls, 35.4 and $37.2 \%$.

The role of different treatments is indicated in Fig. 1, which cleared that there were great differences between the treatments and the control. The most potent effect was for the combination of extract + B.t + GV; its damage index (DI) was 1.7 followed by the others in ascending orders, extract + B.t $(4.2)>$ extract + GV (5.3) > extract (6.5) > B.t + CV (10) > B.t (12) > GV (17.3), when compared with talcum powder (27.3) and untreated tubers (30.0).

\section{Histopathological changes in the endocrine system Changes of the endocrine glands}

Endocrine glands are secretory structures adapted exclusively for producing hormones and releasing them into the circulatory system. Hormone is a chemical signal sent from cells in one part of an organism to cells in another part (or parts) of the same individual. They are often regarded as chemical messengers. They may cause profound changes in their target cells. Their effect may be stimulatory or inhibitory. Insects have several organs that produce hormones, controlling reproduction and metamorphosis. Present research described neurosecretory cells (NSC) in semi-thin section by a light microscope (Fig. 2) and by TEM (Fig. 6a) of P. operculella larvae located in the dorsum of the brain. They send their axons to the corpus cardiacum (CC) (Figs. 3a and 7a), from which the secretory material is discharged into the haemolymph. This hormone activates the prothoracic gland (PRO) (Figs. 5a and 9a) to secret the hormone that stimulates growth and moulting. Immediately behind the corpus cardiacum is a small endocrine gland, the corpus allatum 
Table 1 Effect of different microbial insecticides and basil plant extract on some biological aspects of potato tuber moth Phthorimeae operculitha

\begin{tabular}{|c|c|c|c|c|}
\hline \multirow[t]{2}{*}{ Tested plant powder } & No. of deposited eggs & Duration of life cycle in days & No. of emerged moths & $\%$ Adult offspring $\left(F_{1}\right)$ \\
\hline & \multicolumn{4}{|l|}{ Mean \pm SE } \\
\hline Basil extract + Dipel-2X + GV & $3.0 \pm 0.63 c$ & $42.6 \pm 0.4 d$ & $0.4 \pm 0.4 a$ & 13.30 \\
\hline Dipel-2X + basil extract & $4.0 \pm 1.18 \mathrm{c}$ & $41.4 \pm 0.6 \mathrm{~cd}$ & $1.2 \pm 0.8 c$ & 25.00 \\
\hline Basil extract & $4.6 \pm 1.5 c$ & $30.2 \pm 0.4 a$ & $2.4 \pm 0.6 c$ & 26.92 \\
\hline Basil extract + GV & $5.0 \pm 1.38 c$ & $36.6 \pm 0.2 b$ & $1.8 \pm 0.92 c$ & 26.00 \\
\hline Dipel-2X + GV & $26.2 \pm 2.0 \mathrm{~b}$ & $40.4 \pm 0.2 c$ & $8.6 \pm 0.68 d$ & 25.00 \\
\hline Dipel-2X & $32.4 \pm 4.03 \mathrm{ab}$ & $40.6 \pm 0.4 c$ & $10.8 \pm 0.5 \mathrm{~cd}$ & 33.30 \\
\hline GV & $34.4 \pm 2.00 \mathrm{ab}$ & $35.1 \pm 0.3 b$ & $14.4 \pm 2.8 c$ & 54.96 \\
\hline Talcum powder & $38.2 \pm 0.92 \mathrm{a}$ & $32 \pm 0.95 a$ & $35.4 \pm 0.98 \mathrm{a}$ & 92.20 \\
\hline Untreated tubers & $37.8 \pm 4.2 \mathrm{a}$ & $32.2 \pm 0.8 \mathrm{a}$ & $37.2 \pm 3.87 a$ & 98.40 \\
\hline LSD at 0.05 & 7.3 & 1.59 & 5.2 & \\
\hline LSD at 0.01 & 9.3 & 2.15 & 7.5 & \\
\hline
\end{tabular}

Means with the same letters are not significantly different in vertical column, $P<0.05$

(CA) (Figs. 4a and 8a), which is supplied with nerves from the brain. The CA secrets the juvenile hormone, and so long as it is present in the blood, the growing insect retains its larval characters. In the last larval instar, the CA ceases to secrete this hormone and the insect undergoes metamorphosis to the pupal stage, then the adult stage. It then commonly begins once more to secrete the same hormone, which is now needed for the production of eggs in the ovaries. There are several neurosecretory centres in the brain (Fig. 5). The largest is parce intercerebralis (Fig. 2), which consists of a group of connected secretory cells in variable size with big nucleus occupying most of the cell area as shown in Fig. 6a of the normal neurosecretory cell of PTM larvae. The nucleus is mostly spherical or oval in shape; however, in active cells, it is irregular in shape. Thus, meeting the greater function demand by an increase in volume and dense cytoplasm containing mitochondria, many secretory granules were noticed. Figure $6 \mathrm{~b}$ shows that for the neurosecretory cells of the same age of fed-treated larvae cleared, small amounts of the secretory granules were observed, clumping in nuclear chromatins; cell cytoplasm appears as a fragmented area, the appearance of fat droplets as a sign of autolysis of the cell with disintegration of the mitochondria. The Golgi apparatus in inactive state as it sculls appears empty of secretion. Rough endoplasmic reticulum (RER) cisterna loses its continuity and appears as swollen vacuole or autophagic vacuoles. Corpora cardiac $(\mathrm{CC})$ is a pair of neuroglandular bodies that are found behind the larval brain and on either sides of the aorta. These not only produce their own neurohormones but also store and release other neurohormones including prothoracicotropic hormone (PTTH), which stimulates the secretory activity of the prothoracic glands, playing an integral role in moulting. Figure 6a describes section from a portion of corpora cardiac of normal P. operculella larva (Figs. 3a and 7a). Many dendrites containing neurosecretory granules in variable size were observed. Golgi body between the nerves terminates, and a number of small mitochondria are present. On the other hand, in fed larvae (Figs. 3b and 7b), there was cleared degenerating of the mitochondria. The cristae of mitochondria increased in the inner chamber of the mitochondria, so numerous mitochondria are found in the active cell, there were great quantities of secretory granules, and several dendrites in the area of synaptic terminals are expanded which contain mitochondria neurotubules and small synaptic vesicles. These vesicles contain the chemical transmitter hormones, and gap junctions in the synaptic area decreased the transmission of chemicals or impulses in the corpus cardiacum cells of $P$. operculella fed larvae. Corpora allata (CA) are small, paired glandular bodies located on either side of the larval foregut. They secret the juvenile hormone $(\mathrm{JH})$, which regulates reproduction and metamorphosis. Corpora allata of the normal PTM larvae (Figs. 4a and 7a) clearly presented a big nucleus in a rough endoplasmic reticulum with small size mitochondria; no secretory granules were observed, while in Fig. 7b, obvious secretory granules or exocytoses of neurosecretory material within the intracellular spaces were noticed, synaptic vesicles clumping in nuclear chromatin, swelling, and protruding in size (Fig. 4b); darkening and deformed mitochondria (Fig. 4b) and autophagic vacuoles were observed in the corpora allata of the fed larvae. Prothoracic glands (PRO) in $P$. operculella larvae are diffuse with paired glands located at the back of the head (Fig. 8). These glands secrete an ecdysteroid called ecdysone, or the moulting hormone, which initiates the epidermal moulting process. Additionally, it plays a role in accessory reproductive glands in the 


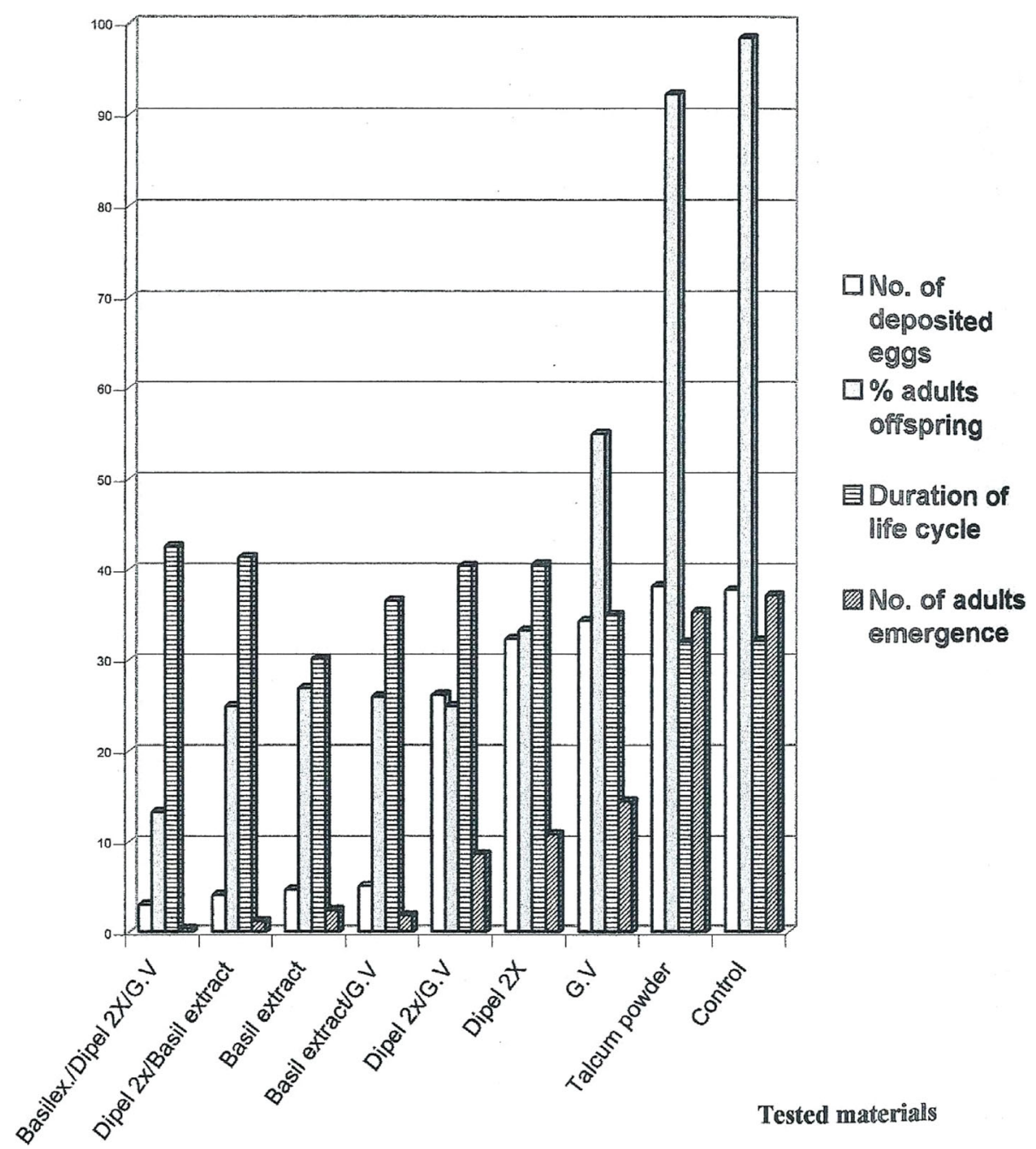

Fig. 1 Damage index in potato tubers treated with different microbial insecticides and basil extract

female, in differentiation of ovarioles, and in the process of egg production. The section through prothoracic glands in normal $P$. operculella larvae (Figs. 5a and 9a) shows a group of cells with big rounded nucleus and small mitochondria in the cell cytoplasm. Figures $5 \mathrm{~b}$ and $9 \mathrm{~b}$ show that for the prothoracic gland of the fed larvae, irregular nuclear membrane, lost of cell membranes, clumping of nuclear chromatin, lysosome noticed in the cytoplasm, fat droplets observed inside the nucleus, and many areas of the cell cytoplasm encircled by a membrane lead to the formation of autophagocytic vacuoles, in which cells destroy their own product. Figure $8 \mathrm{~b}$ is also referred to as cytoplasmic degeneration leading to severe damage and even death of the cell. The histological changes that were noticed between the normal and treated neuroendocrine glands of PTM larvae were noticed as increasing in nuclear size and extensiveness of dendrites and mitochondria as a result of overexertion of the cell and increasing of the secretory activity. Forementioned changes indicated disorder of the combined formulation as a growth disruptor for $P$. operculella.

\section{Discussion}

From the results in Table 1, it was clear that the combination of the three additives (B.t + GV + basil extract) was the most potentiating mixture in decreasing the number of eggs laid by female moth on the treated tubers, followed by all treatments that contained the basil extract. The presence of the basil extract plays a role as repellent against the female moth which possesses olfactory and contact chemoreceptors that were located on the ovipositor, and tarsus and antennae were repelled by the odour of volatile or chemical constituents of the plant (Sharaby et al. 2002). Plant odour acts as feeding and oviposition deterrents to a wide variety of insect pests. It was also effective as fumigant (Koul et al. 2008). Rivera and Retamoza (2000) mentioned that reduction in oviposition may have been induced by the change in 


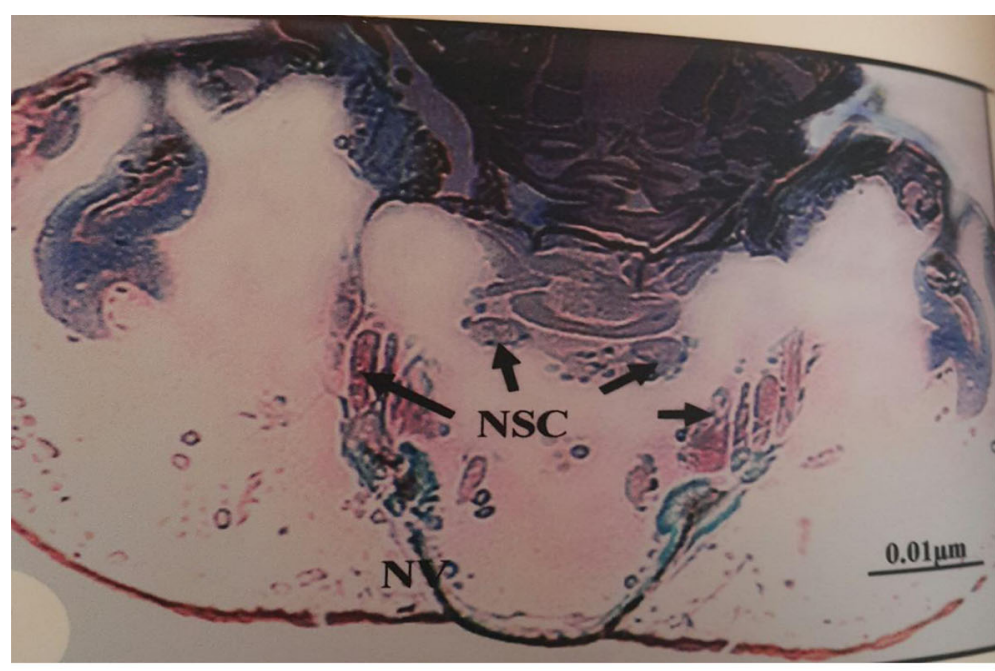

A Neurosecritory cells (NSC) in brain black arrows

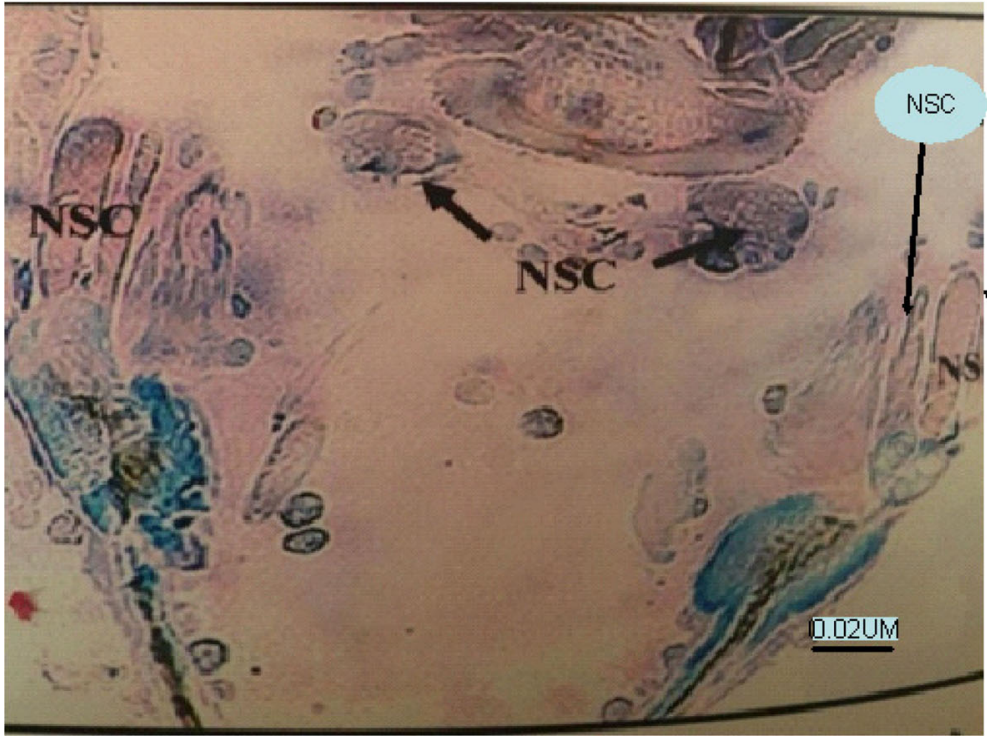

B Magnification of Fig. (2)

Fig. 2 Neurosecretory cells (NSC) in the brain, black arrows. Semi-thin sections by a light microscope in different parts in the endocrine organs in larvae of the potato tuber moth Phthorimeae operculella (a normal and $\mathbf{b}$ treated larvae). Abbreviations: NSC neurosecretory cells in medial cerebral, NV nerve, CC corpora cardiac, NC nerve cells, NL neural lamella, D dendrites, HS droplets of secretion, SG salivary gland, HSD hormone secretion droplets, NM neuropile mass, CA corpus allatum, AO aorta, Tr tracheoles, Pg prothoracic gland, C cell body, M membrane, BM basal membrane

the appearance of the treated crops, thus making the crops unattractive to the insect. Egg-laying inhibition, which is significant, is responsible for low crop damage, probably due to egg-laying deterrent effects of some plant powders and their odour. Most insects breathe through the trachea, which usually leads to the opening of their spiracle, and these spiracles might be blocked by the powders, thereby leading to suffocation (Komabonta and Falodu 2013). Sharaby (1988) mentioned that reproduction in the PTM was significantly reduced when either males or females were exposed to the vapour of orange peel oil. In addition, a pronounced reduction in egg production and egg viability occurred when the moths were exposed to the odour arising from plant oils. White (1973) in his early studies showed that basil oil is rich in monoterpenes, sesquiterpenes, and phenylpropane derivatives that induced the larvicidal activity of $O$. basilicum against mosquito. Basil proved to have an insect repellence effect and possessed juvenile hormone (Desphande 1977). Mahmoud et al. (2017) recorded an 


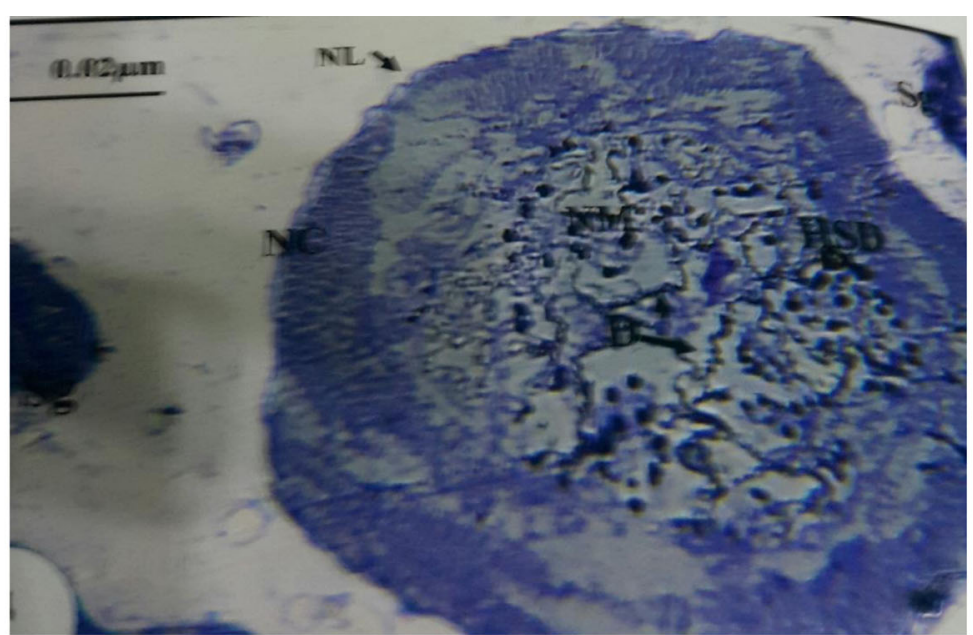

A Normal corpus cardiacum (CC)

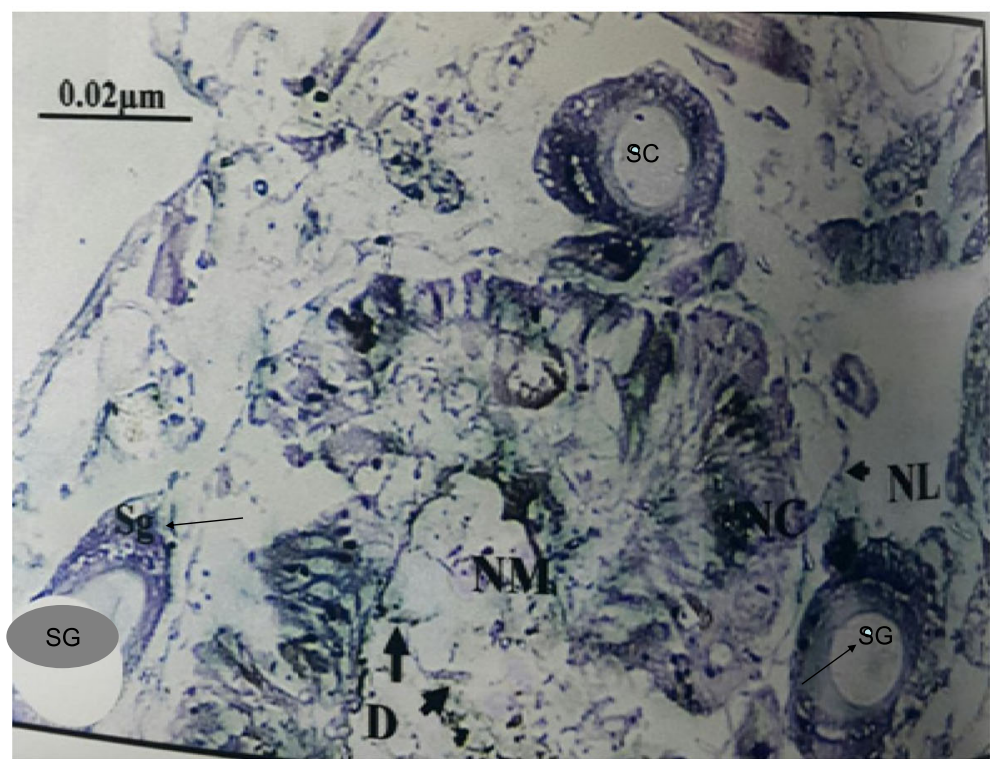

\section{B Treated corpus cardiacum}

Fig. 3 a Normal corpus cardiacum (CC). b Treated corpus cardiacum. Semi-thin sections by a light microscope in different parts in the endocrine organs in larvae of the potato tuber moth Phthorimeae operculella (a normal and $\mathbf{b}$ treated larvae). Abbreviations: NSC neurosecretory cells in medial cerebral, NV nerve, CC corpora cardiac, NC nerve cells, NL neural lamella, D dendrites, HS droplets of secretion, SG salivary gland, HSD hormone secretion droplets, NM neuropile mass, CA corpus allatum, AO aorta, Tr tracheoles, Pg prothoracic gland, C cell body, M membrane, BM basal membrane

effect of basil (Ocimum basilicum) leaf powder and its ethanolic extract against the third larval instar of Anopheles arabiensis. A leaf extract of $O$. basilicum was used in formulating an aerosol and mosquito coil (Umerie et al. 1998). The repellent effect of basil constituents was recorded also on Ixodes ricinus ticks (Fabbro and Nazzi 2008). In the present research, plant extract has an essential role to facilitate the potency of B.t and GV; results revealed that all treatments containing plant extract greatly affect the insect development in terms of larval duration, percentage of adult $F_{1}$ emergence, and egg production and hatchability. This may be correlated to the chemical constituents of basil extract. A marked increase was observed in the potency of B.t and GV preparation against PTM when combined with basil extract in varying grades. Aromatic plants like basil are rich in essential oils, which show vapour toxicity towards adult, and inhibit reproduction by ovicidal and larvicidal effects (Hiba et al. 2017). Korstykovsky et al. (2002) mentioned that the rapid action against some pests is 


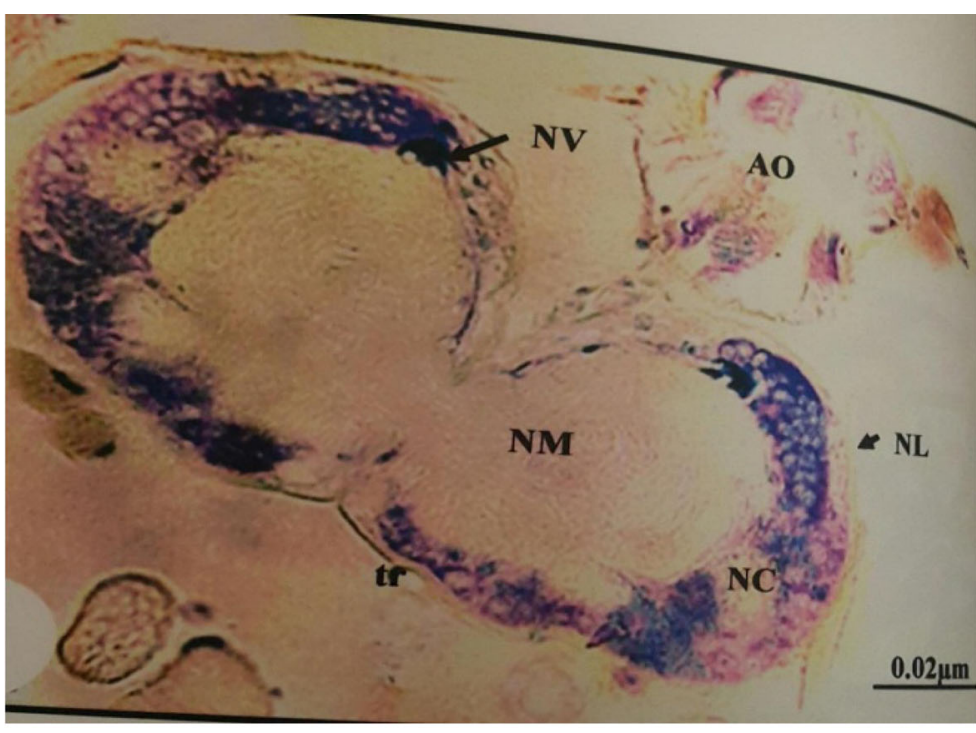

A Normal corpora allata (CA)

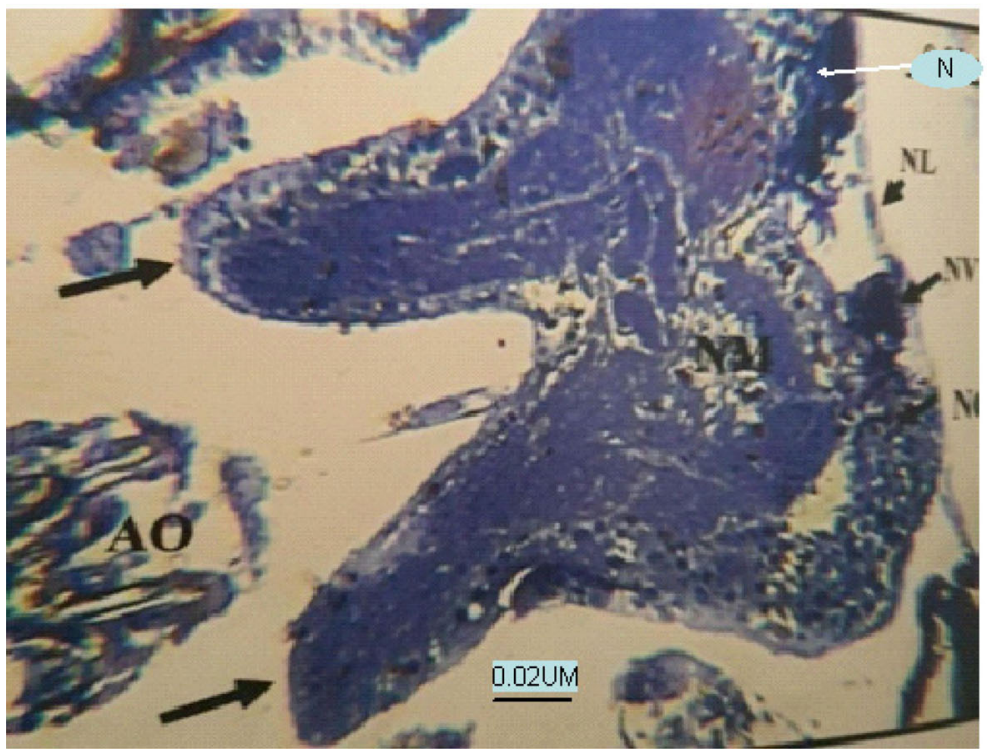

B Treared corpora allata(CA)

Fig. 4 a Normal corpora allata (CA). b Treated corpora allata (CA). Semi thin sections by light microscope in different parts in the endocrine organs in larvae of the potato tuber moth Phthorimeae operculella (a normal and $\mathbf{b}$ treated larvae). Abbreviations: NSC neurosecretory cells in medial cerebral, NV nerve, CC corpora cardiac, NC nerve cells, NL neural lamella, D dendrites, HS droplets of secretion, SG salivary gland, HSD hormone secretion droplets, NM neuropile mass, CA corpus allatum, AO aorta, Tr tracheoles, Pg prothoracic gland, C cell body, M membrane, BM basal membrane

indicative of a neurotoxic mode of action, and there is evidence for interference with the neuromodulator octopamine. Low number of emerged moth may be a result of a reduction in egg hatchability, which agreed with that mentioned by Schmidt et al. (1991) that egg hatchability of Callosobrucus chinensis (L.) was reduced after 96-h exposure to vapour of Acorus calamas (L.), attributing that to the toxicity of vapours to eggs. The volatiles of the plant which probably diffused into eggs and affected the vital physiological and biochemical process associated with embryonic development. The embryonic development in these eggs was not relatively complete. Also, retardation in larval development that finally ends with death was related to the effect of the microbial pesticides (B.t and GV), which damaged the larval tissues. Heimple and Angus (1959) recorded the earliest report on the mode of action of $\alpha$-endotoxin of B.t has in the gut of larvae some proteolytic enzyme capable of 


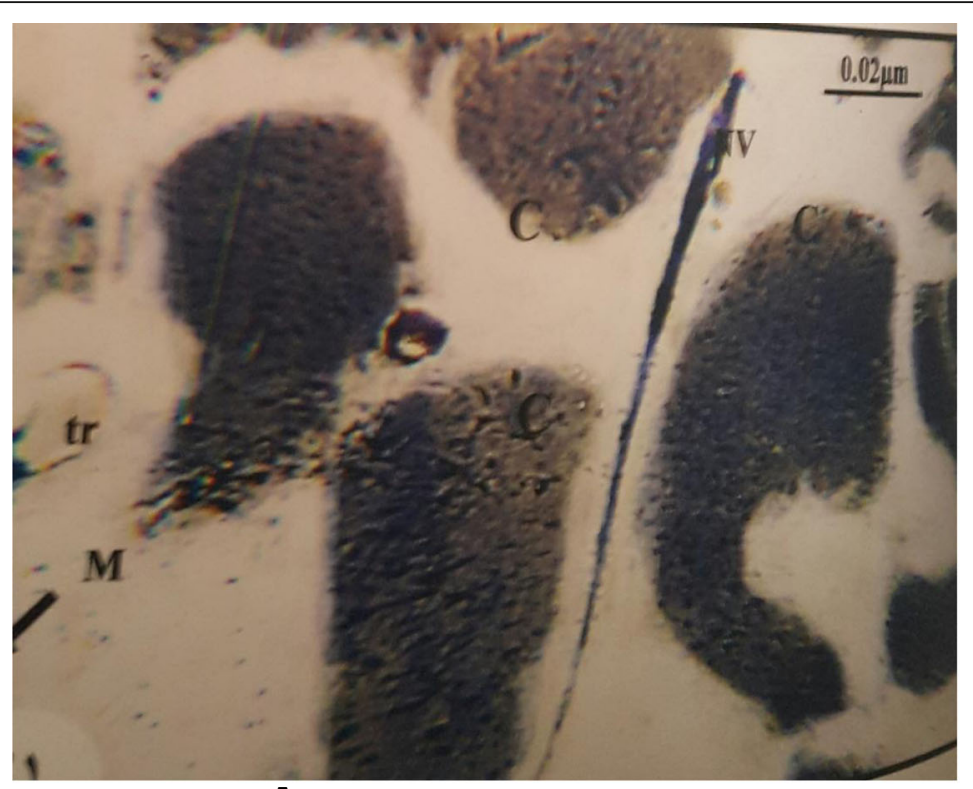

A Normal prothoracic gland (PRO)

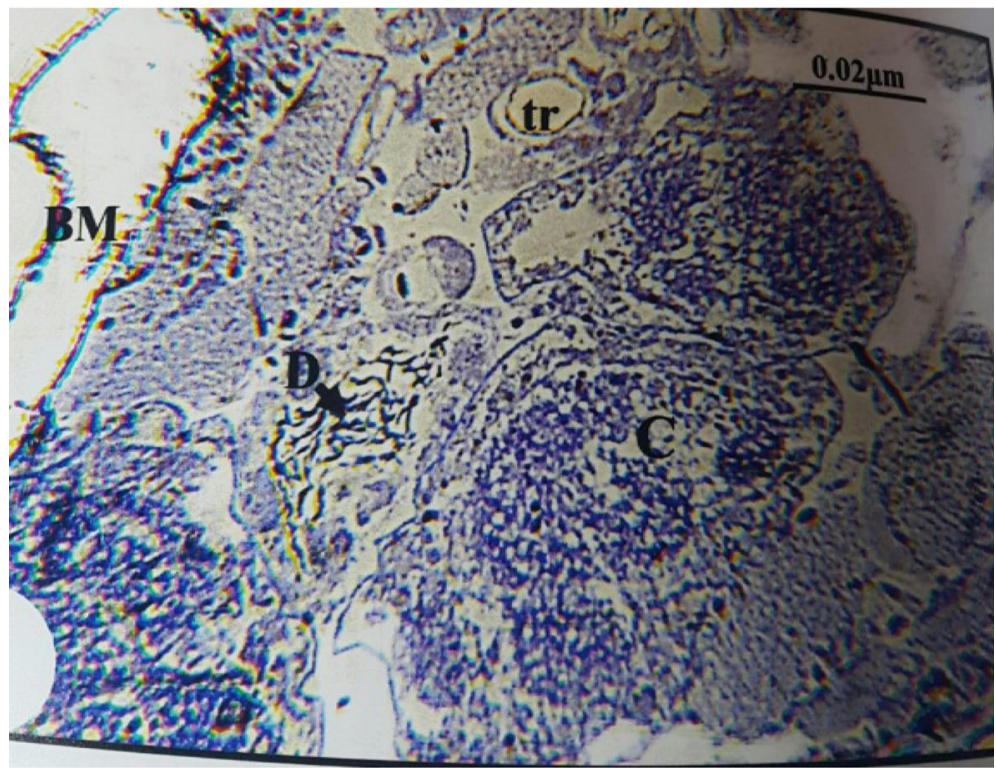

B Treated prothoracic gland

Fig. 5 a Normal prothoracic gland (PRO). b Treated prothoracic gland. Semi thin sections by light microscope in different parts in the endocrine organs in larvae of the potato tuber moth Phthorimeae operculella (a normal and $\mathbf{b}$ treated larvae). Abbreviations: NSC neurosecretory cells in medial cerebral, NV nerve, CC corpora cardiac, NC nerve cells, NL neural lamella, D dendrites, HS droplets of secretion, SG salivary gland, HSD hormone secretion droplets, NM neuropile mass, CA corpus allatum, AO aorta, Tr tracheoles, Pg prothoracic gland, C cell body, M membrane, BM basal membrane

breaking down the crystals in the midgut; when the larvae eats $\alpha$-endotoxin, certain pathological changes take place. First, the gut becomes paralyze, accompanied with significant damage to the intestinal wall. These changes are followed by toxaemia and/or septicemia taking place sometime after the gut paralysis, which showed prolongation in the larval period. Granulosis virus is also from ingestion during larval feeding to the midgut, releasing the virus particles into the gut lumen, following fusion between cells and released into cell cytoplasm and are transported to the nucleus, where transcription and replication occur. Into the cytoplasm, nucleocapsids are transported from the basal membrane to the haemocoel, damaging other tissues in larvae: connective tissues, fat bodies, epithelial cells, and nerve ganglia (Washburn et al. 2003). The obtained data cleared that 


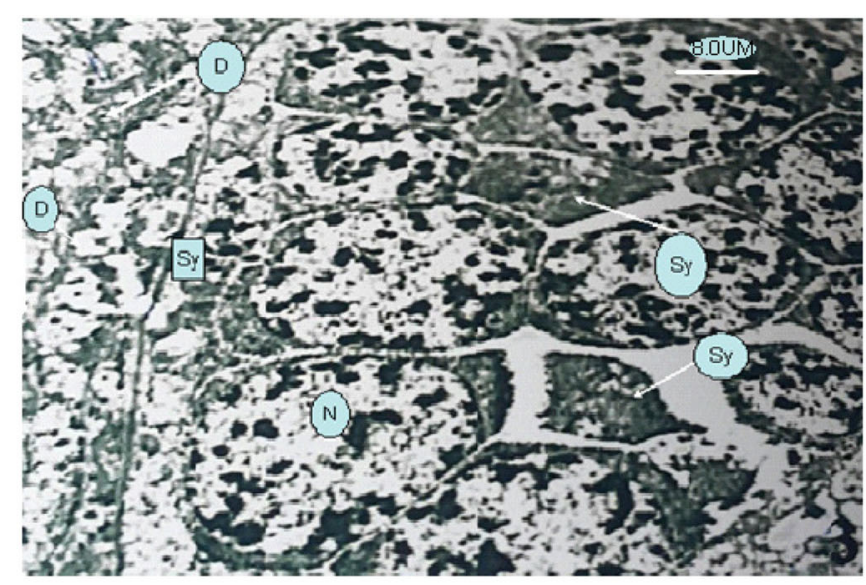

A Normal neurosecritory cells (NC) in the brain of the larva, white arrows showed points of synaptic clusters.

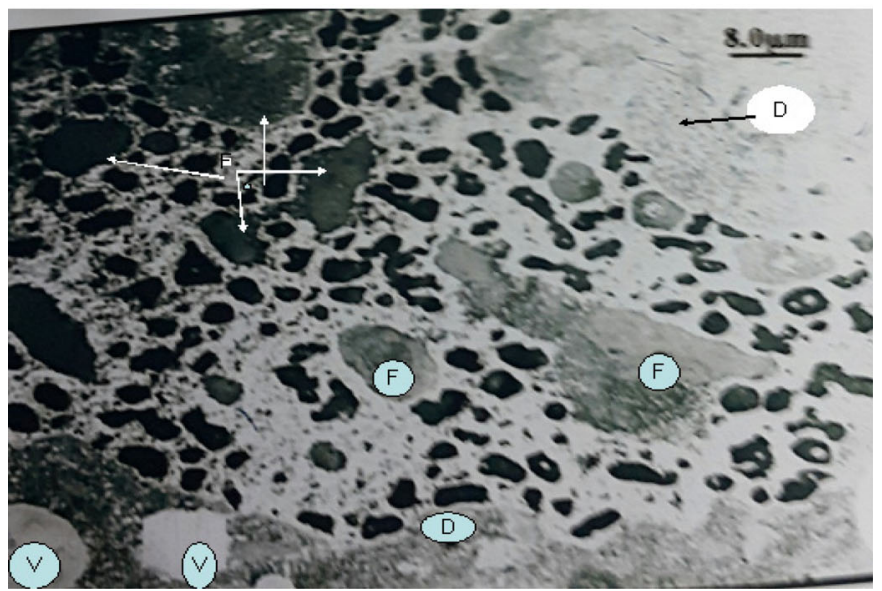

B Neurosecritory cells (NC) in the brain of the treated larva, whit arrows showed fat droplet in the cell cytoplasm

Fig. 6 a Normal neurosecretory cells (NC) in the brain of the larva. White arrows showed points of synaptic clusters. b Neurosecretory cells (NC) in the brain of the treated larva. White arrows showed fat droplet in the cell cytoplasm. Sections in different tissues of the endocrine system of the potato tuber moth Phthorimaea operculalla larva detected under electron microscope observation. a The normal untreated tissues. $\mathbf{b}$ Treated tissues of larva reared on potato tubers covered with talcum powder containing 0.5\% each of basil extract + B.t + GV and $25 \mathrm{~g} / 1 \mathrm{~kg}$ tuber. Abbreviations: NC neurosecretory cells, CC corpus cardiacum, CA corpus allatum, PRO prothoracic gland, N nucleus, D dendrites, sy synaptic vesicles, V vacuoles, F fat droplets, M cell membrane, Nm nuclear membrane, Cy cytoplasm, A axon, nl necrosis, F fat droplets, Mt mitochondria

an additive effect was obtained when the two pathogens were used; more protection was recorded to the tubers when used in combination than if used separately. Also, data revealed that B.t was more effective or more pathogenic to the larvae followed by GV, and there was an additive effect of the two pathogens after the combination treatment. The possible entry of B.t and subsequent toxin release caused a partial destruction of the cell organelles, which facilitated the entry of the virus from the neighbouring fat tissues. Matter and Zohdy (1981) explained that the synergistic effect or the two pathogens, B.t and virus, on Heliothes armigera may result from retardation in larval development induced by the bacterium, thus giving the opportunity to the virus to propagate causing its effect. Combining inhibitors and disruptors, the endocrine glands of the larvae significantly increased larval and pupal duration inside the tubers and decreased the percentage of moths' emergence and egg production by $F_{1}$ moths if compared with the control. The fecundity and fertility of females resulted from larvae fed on the treated tubers were remarkably decreased, compared with the control. Ultrastructure changes of the endocrine glands of the treated larvae fed on the combined formulation detected by TEM cleared that many changes occurred in all their parts; reflecting on the larval development and moths progeny proved 


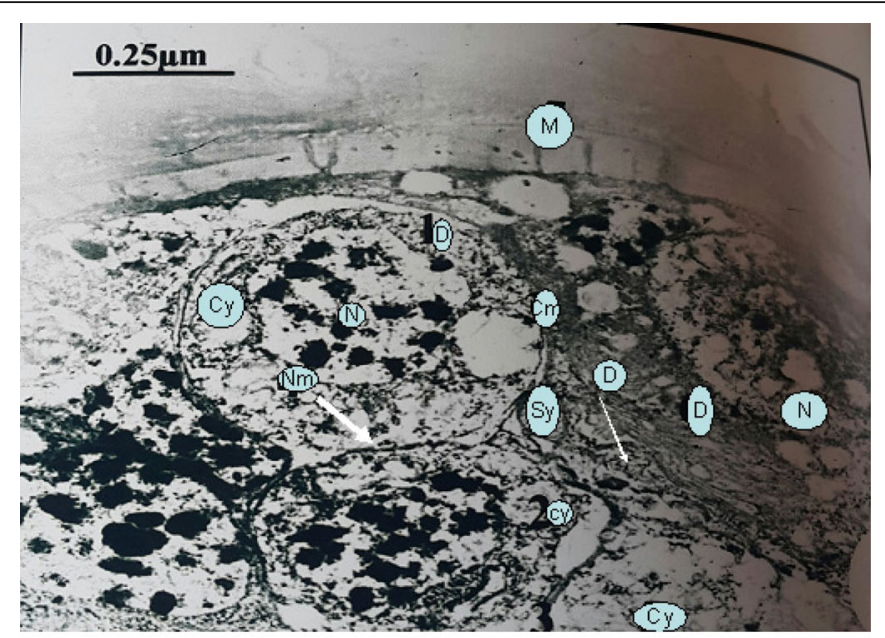

A Normal corpora cardiacum (CC) in untreated larva. White arrow showed dendrites.

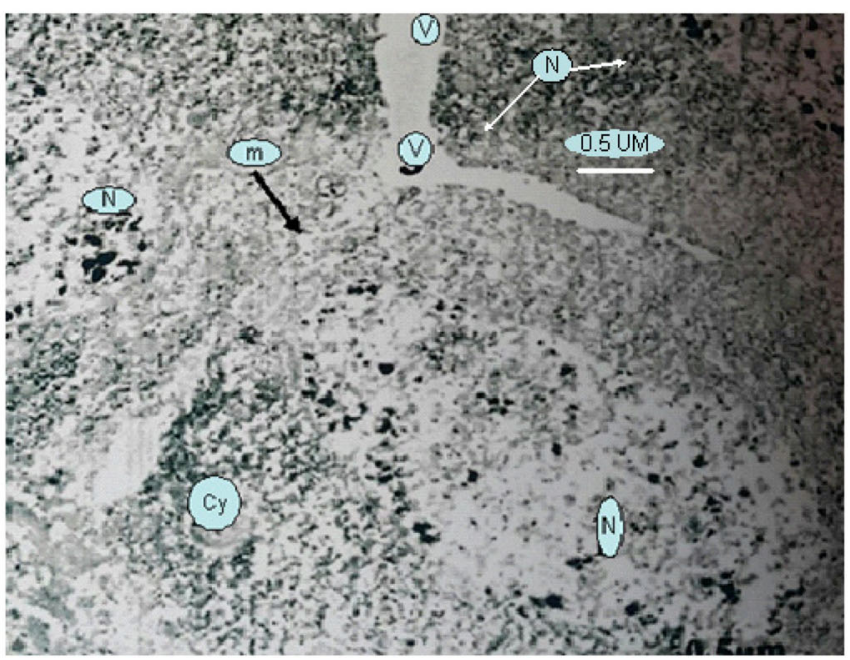

B Cells of corpus cardiacum (CC) in treated larva.

Fig. 7 a Normal corpora cardiacum (CC) in untreated larva. White arrow showed the dendrites. b Cells of corpus cardiacum (CC) in treated larva. Sections in different tissues of the endocrine system of the potato tuber moth Phthorimaea operculalla larva detected under electron microscope observation. a The normal untreated tissues. $\mathbf{b}$ The treated tissues of larva reared on potato tubers covered with talcum powder containing $0.5 \%$ each of basil extract + B.t + GV and $25 \mathrm{~g} / 1 \mathrm{~kg}$ tuber. Abbreviations: NC neurosecretory cells, CC corpus cardiacum, CA corpus allatum, PRO prothoracic gland, N nucleus, D dendrites, sy synaptic vesicles, $V$ vacuoles, F fat droplets, M cell membrane, Nm nuclear membrane, Cy cytoplasm, A axon, nl necrosis, F fat droplets, Mt mitochondria

that the formulation acts as growth disruptor or regulator. With reference to histological changes, treatment of neurosecretory glands for balancing hormone secretion affects metamorphosis, development, and reproduction of the resulting moths. Sieber (1982) mentioned that neem extracts increase the secretion in the neurosecretory cells in pars intercerebralis of Locosta migratoria that transferred through corpora cardiaca which activate the release of $\beta$-ecdyson in great quantities leading to disadvantages in cuticle formation and fat bodies. Smagghe et al. (1996) found that tebufenozide affected the neurosecretory cells of Plodia interpunctella and activated the epidermal cells leading to deformation in $\mathrm{cu}^{-}$ ticle formation and disintegrations in cell organelles as a result of hormonal unbalance. Schluter (1985) recorded that corpora allata and corpora cardiaca cell glands increased in size and degenerated as a result of neem extract treatment for Epilachna vaeivestis. The endocrine system was affected by growth regulators such as tebufenozide which cause damage for the cell organelles as a result of an imbalance in hormone secretions (Rentakam et al. 1997). It is concluded that the combined 


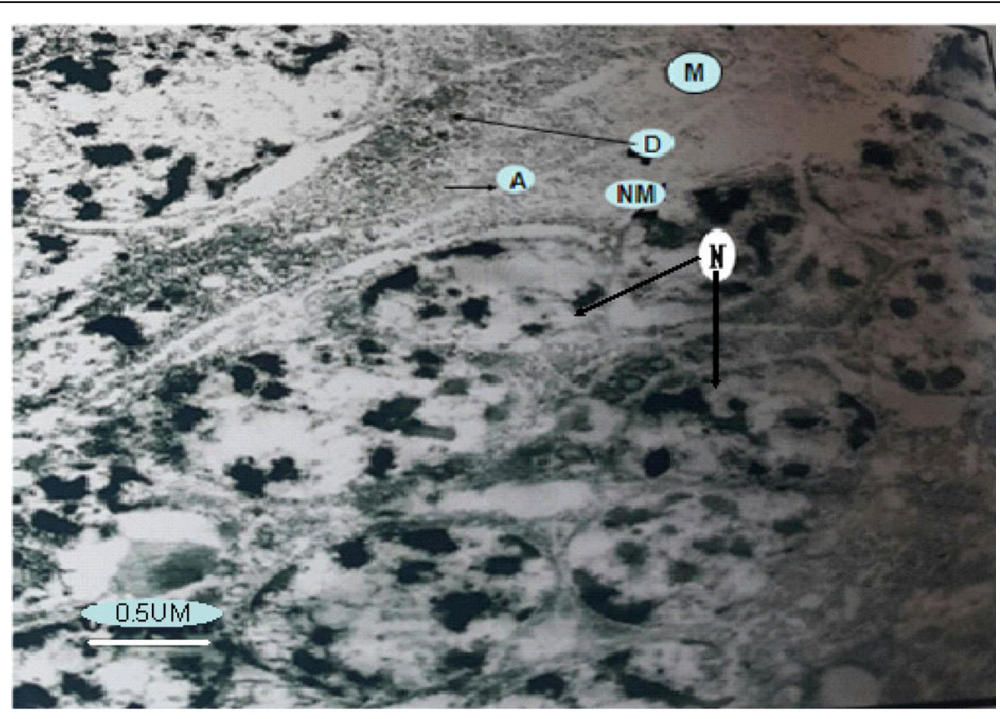

A Cells of corpus allatum (CA) in normal larva

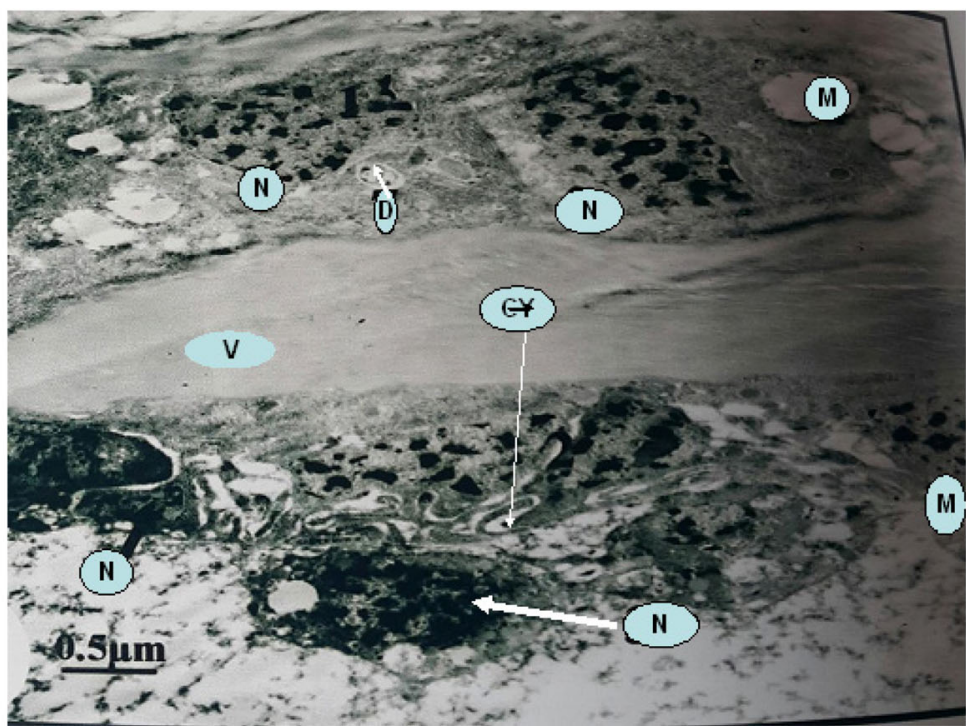

B Corpus allatum $(\mathrm{CA})$ in treated larva

Fig. 8 a Cells of corpus allatum (CA) in normal larva. b Corpus allatum (CA) in treated larva. Sections in different tissues of the endocrine system of the potato tuber moth Phthorimaea operculalla larva detected under electron microscope observation.a The normal untreated tissues. $\mathbf{b}$ The treated tissues of larva reared on potato tubers covered with talcum powder containing $0.5 \%$ each of basil extract + B.t + GV and $25 \mathrm{~g} / 1 \mathrm{~kg}$ tuber. Abbreviations: NC neurosecretory cells, CC corpus cardiacum, CA corpus allatum, PRO prothoracic gland, N nucleus, D dendrites, sy synaptic vesicles, $\mathrm{V}$ vacuoles, F fat droplets, M cell membrane, Nm nuclear membrane, Cy cytoplasm, A axon, nl necrosis, F fat droplets, Mt mitochondria

formulation interferes with the physiological role of the endocrine glands modifying their structure and activity leading to disturbed synthesis and release of neurosecretory material, or may affect the endocrine gland activity in an indirect way.

Combination of basil extract + B.t $+\mathrm{GV}$ induced a promising effect as a protector for the potato tubers against the PTM infestation during the storage period and reduces the need for the use of chemical insecticides and their associated risks. The obtained results suggested an interesting opportunity to develop bioinsecticides based on plant extracts for the control of this serious lepidopteran pest and other pests during storage that may affect production and marketing. From this point of view, and so, usage of the mentioned combined mixture for the control and protection of the 


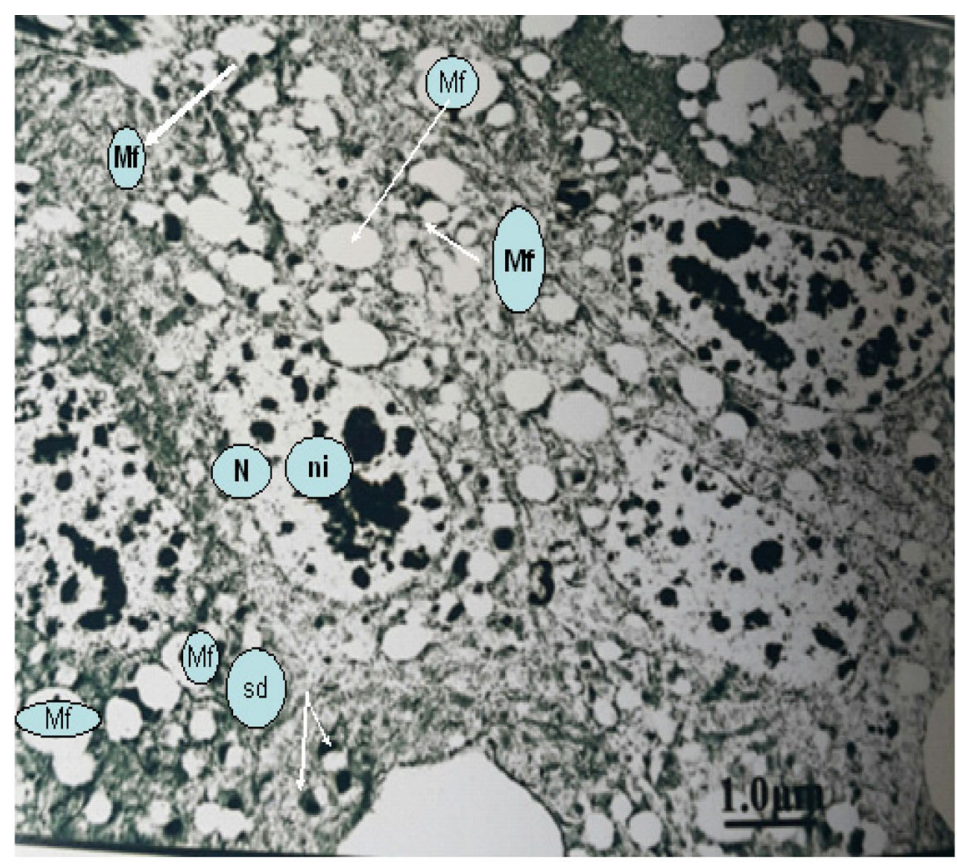

A Cells in prothorasic gland (PRO) in normal larva

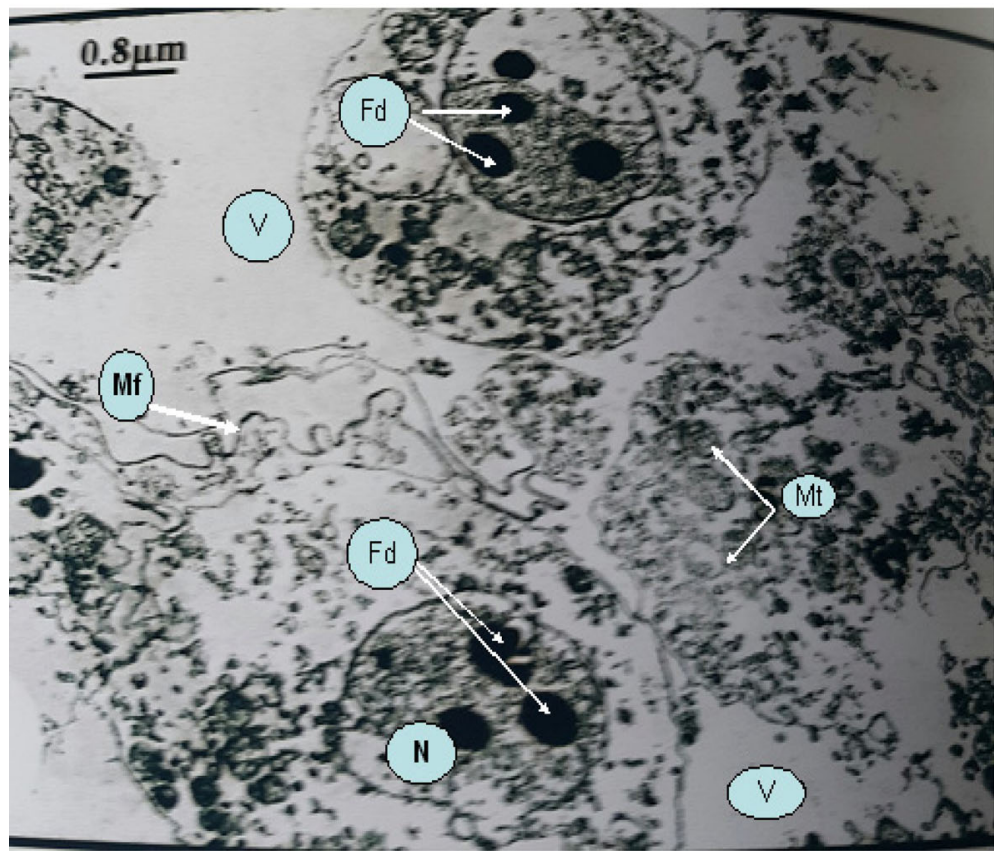

B Cells in prothorasic gland (PRO) of the treat larva

Fig. 9 a Cells in prothoracic gland (PRO) in normal larva. b Cells in prothoracic gland (PRO) of the treated larva. Sections in different tissues of the endocrine system of the potato tuber moth Phthorimaea operculalla larva detected under electron microscope observation. a The normal untreated tissues. $\mathbf{b}$ The treated tissues of larva reared on potato tubers covered with talcum powder containing $0.5 \%$ each of basil extract + B.t + GV and $25 \mathrm{~g} / 1 \mathrm{~kg}$ tuber. Abbreviations: NC neurosecretory cells, CC corpus cardiacum, CA corpus allatum, PRO prothoracic gland, N nucleus, D dendrites, sy synaptic vesicles, $\mathrm{V}$ vacuoles, F fat droplets, M cell membrane, Nm nuclear membrane, Cy cytoplasm, A axon, nl necrosis, F fat droplets, Mt mitochondria 
tubers from increasing their toxicity and decreasing insect resistance build-up as a biological method through IPM program could be recommended.

\section{Conclusion}

The research revealed that an additive effect was produced using a combination of three bioagents (basil plant extract + B.t + GV) against the potato tuber moth Phthorimaea operculella. Combination of the three additives in one formulation may reduce the initial amount of potato destruction and reduce the need for and risks associated with the use of chemical insecticides. The obtained results suggested an interesting opportunity to develop bio-insecticides based on plant extracts for the control of this serious lepidopteran pest and other pests during storage, which may affect production and marketing. From this point of view, and so, the usage of the mentioned combined mixture for the control and protection of the tubers from increasing their toxicity and decreasing insect resistance build-up as a biological method through IPM program could be recommended.

\section{Author declaration}

All authors declare that the manuscript has not been sent for consideration for publication or for publication anywhere else before, and the manuscript is original research data.

\section{Significant statements}

An eco-friendly approach can be followed for sustainable development of the nature and its dependents. It can be concluded that the tested plant powders have high potential as natural protector to the stored potatoes against TPM.

\section{Authors' contributions}

ASH suggested the research idea, designed the experiments, wrote the manuscript, reviewed the data, and edited and approved the manuscript. MAG wrote the manuscript, reviewed the data, managed the tables and figures, and edited and approved the manuscript. SBF made the experiments, recorded and analysed the data, prepared the tables, assisted in writing up the manuscript, and approved the manuscript.

\section{Funding}

The experimental work is not financially funded by any agent.

\section{Availability of data and materials}

All data on which the abstract of the study has been drawn are presented in the main manuscript.

\section{Ethics approval and consent to participate}

Not applicable

\section{Consent for publication}

Not applicable

\section{Competing interests}

The authors declare that they have no competing interests.

\section{Author details}

${ }^{1}$ Pests \& Plant Protection Department, Agricultural \& Biological Researches Division, National Research Centre, Cairo, Egypt. ${ }^{2}$ Biology Department, College of Science, Imam Abdel Rahman Bin Faisal University, Dammam, Kingdom of Saudi Arabia.
Received: 12 May 2019 Accepted: 12 July 2019

Published online: 26 July 2019

\section{References}

Abbott WS (1925) A method of computing the effectiveness of insecticide. J Eccol Entomol 18:265-267

Akhtar Y, Isman MB (2004) Comparative growth inhibitory and antifeedant effect of plant extracts and pure allelochemicals on four phytophagous insect species. J Appl Ent 128:32-38

Desphande EL (1977) Mosquito larvicidal activity of Ocimum basillicum Linn. Pesticides 11(5):11-12

Fabbro S, Nazzi F (2008) Repellent effect of sweet basil compound on Ixodes ricinus tick. Exp Appl Acarol 45(3-4):219-228

Fenemore PG (1980) Oviposition of potato tuber moth Phthorimaea oprculell (Zell.) (Lepidoptera: Geleshiidae) identification of host plant factors influencing oviposition response, N. Z. J. Zool 7:435-439

Heimple AU, Angus TA (1959) The site of action of crystalliferous bacteria in Lepidoptera larvae. J Insect Pathol 1:152-170

Hiba EMAM, Nabil HHB, Yousif OHA (2017) Effect of basil Ocimum basilicum leaves powder and Ethanolic-extract on the $3^{\text {rd }}$ larval instar of Anopheles arabiensis (Patton,1905) (Culicidae: Diptera). Int J Mosq Res 4(2):52-56

Komabonta KA, Falodu BB (2013) Bioefficacy of three plant products as postharvest grain Sitophillus oryzae Linnacus (Coleoptera: Curculionidae) on stored wheat (Triticum aestivum). IJSN 4(2):259-264

Korstykovsky MA, Rafaeli C, Gilradi N, Den chenko E, Shaaya E (2002) Activation of octopaminergic receptors by essential oil constituents isolated from aromatic plants: possible mode of action against insect pests. Pest Manag Sci 58:1101-1106

Koul O, Walia S, Dhaliwal GS (2008) Essential oils as green pesticides: potential and constrains. Biopestic Int 4(1):63-84

Mahmoud HEMA, Bashir NHH, Assad YOH (2017) Effect of basil (Ocimun basilicum) leaves powder and ethanolic-extract on the $3^{\text {rd }}$ larval instar of Anopheles arabiensis (Patton, 1905) (Culicidae: Diptera). Int J Mosq Res 4(2):52-56

Matter MM, Zohdy NMZ (1981) Biotic efficiency of Bacillus thuringiensis Berl. and a nuclear polyhedrosis virus on larvae of the American bollworm, Heliothes armigera Hbn (Lepidoptera, Noctuidae). Z Angew Entomol 92:336-343

Mazid S, Kalita JCH, Rajkhowa RCH (2011) A review on the use of biopesticides in insect pest management. IJSART 1(7):169-178

Onu FM, Ogu E, Ikehi ME (2015) Use of neem and garlic dried plant powders for controlling some stored grains pests. Egypt J Biol Pest Control 25(2):507-512

Rentakam A, Macdonald A, Tomkins W, David C, Brownwright A, Palli SR (1997) Ultrastructure effects of non-steroidal ecdyson agonist, $\mathrm{RH}-5992$, on the $6^{\text {th }}$ instars larvae of the spruce budworm, Cheristoneure fumiferana, (Bibliographic citation). J Insect Physiol 43(1):55-68

Rivera NC, Retamoza RC (2000) Potato moth control with local plants in the storage of potato. In: Stoll G (ed) Natural crop protection in the tropic, Margraf Verlage, P.O. box.1205, Weikersheim, pp 313-320

Rondon SI (2010) The potato tuberworm: a literature review of its biology, ecology and control. Am J Potato Res 87:149-166

Salama HS, Sharaby A (1985) Histopathlogical changes in Heliothes armigera infested with Bacillus thuringiensis as detected by electron microscopy. Insect Sci Applic 6(4):505-511

Schaub B, Kroschel J (2018) Developing a biocontrol strategy to protect stored potato tubers from infestation with potato tuber moth species in the Andean region. J Appl Entomo 142:78-88

Schluter U (1985) Disturbance of epidermal and fat body tissue after feeding azadirachtin and its consequence on larval moulting in the Mexican bean beetle, Epilachna varivestis (Col. Coccinellidae). Ent Ger 10:97-110

Schmidt GH, Risha EM, EL-Nahal AKM (1991) Reduction of progeny of some stored-product coleopteran by vapour of Acorus calamus oil. J Stored Prod Res 27(2):121-127

Sharaby A (1988) Effect of orange, Citrus sinensis (L.) peel oil on reproduction in Phthorimaea operculella (Zeller). Insect Sci Appl 9:201-203

Sharaby A, Abdel Rahman HA, Moawad S (2002) Sensors of the potato tuber moth Phthorimaea operculella (Zeller) (Lepidoptera: Geleshiidae). Bull NRC Egypt 27(1):131-147

Sharaby A, Fallatah S (2019) Protection of stored potatoes from infestation with the potato tuber moth, Phthorimaea operculella (Zeller) (Lepidoptera: Gelechiidae) using plant powders. Bull NRC Egypt 43:79-85 
Sieber KP (1982) Untersuchngen uber die wirkung des Azadirachtin auf die Entwicklung und ihre steuerung bie Locosta migratoria. Ph.D. Thesis, Univ. of Munich, FRG

Smagghe G, Salem H, Degheede D (1996) Tebufenuzide effects on nonsteroidal ecdysreroid agonist on cuticle formation in Indian meal moth, Plodia interpunctella larvae. (bibliographic citation). Parasitica. 52(4):143-151

Srinivasan R (2012) Integrating biobesticides in pest management strategies for tropical vegetable production. J Biopest 5:36-45

Stevenson PC (2014) Using pesticidal plants for crop protection. Poyal Botanic Gardens http://www.kew.org/discover/blogs/using-pesticidal-plants-cropprotection (Accessed 22 Mar 2015

Umerie SC, Anaso LJ, Anyasoro IJC (1998) Insecticidal potentials of Ocimum basilicum leaf-extract. Bioresour Technol 64(3):237-239

Washburn JO, Chan EY, Volkman LE, Aumiller JJ, Jarvis DL (2003) Early synthesis of budded virus envelope fusion protein GP64 enhances Autographa californica multicapsid nucleopolyhedrovirus virulence in orally infected Heliothes virescens. J Virol 77:280-290

White GB (1973) Comparative studies on sibling species of the Anopheles gambia Giles complex (Dipt., Culicidae). The distribution ecology, behavior and vectorial importance of $D$ in Bwamba country, Uganda, with an analysis of biological, ecological, morphological and cytological relationships of Uganda species D. Bull WHO 63:56-97

Xu XM (2011) Combined use of biocontrol agents to manage plant diseases in theory and practice. Phytopathol. 101:1024-1031

\section{Publisher's Note}

Springer Nature remains neutral with regard to jurisdictional claims in published maps and institutional affiliations.

\section{Submit your manuscript to a SpringerOpen ${ }^{\circ}$ journal and benefit from:}

- Convenient online submission

- Rigorous peer review

- Open access: articles freely available online

High visibility within the field

- Retaining the copyright to your article

Submit your next manuscript at $\boldsymbol{\nabla}$ springeropen.com 